\title{
Youth Perspectives on Intergenerational Solidarity in Families
}

\author{
Genç Nesil Bakışıyla Ailelerde Nesiller Arası Dayanışma
}

\author{
Serhat Öztürk* ${ }^{1}$, Oya Hazer ${ }^{l}$
}

\begin{abstract}
Objectives: This study aims to determine intergenerational solidarity in families, and examine the scores and relations of the dimensions of intergenerational solidarity (Normative solidarity, Affectual solidarity, Associational solidarity, Consensual solidarity, Functional solidarity, Structural solidarity). Method: A sample of 1006 young people age between 15-29 from the socio-economic levels participated in the study, and their intergenerational solidarity were determined by the theory Bengtson's Intergenerational solidarity. Results: It was found that there are some statistically significant relationships between normative solidarity and consensual solidarity, age, functional solidarity, education level of parents/grandparents, number of siblings and gender. Conclusion: Intergenerational solidarity was found over middle levels. Accordingly, intergenerational solidarity in families has to be maintained and strengthened by all the units like government and nongovernmental organizations with projects and programmes.
\end{abstract}

Key words: Intergenerational solidarity, family support, care

\section{ÖZET}

Amaç: $\mathrm{Bu}$ araştırmada, ailelerde nesiller arası dayanışma boyutlarını (normatif dayanışma, duygusal dayanışma, ilişkisel dayanışma, işlevsel dayanışma, uzlaşımsal dayanışma ve yapısal dayanışma) ve bu boyutlar arasındaki ilişkinin incelenmesi ile aile yaşantısını güçlendirme, nesiller arası beklentilerin anlaşılması ve nesiller arasındaki sorunlara çözüm yolları bulunması amaçlanmıştır. Yöntem: Ankara'nın üç farklı sosyo-demografik bölgesinde, farklı yaş gruplarındaki (15-29 yaş) 990 gence, nesiller arası dayanışmaya ilişkin sorular yöneltilmiş ve katılımcılar bu soruları annelerinden, babalarından, büyük annelerinden ya da büyük babalarından bir tanesini dikkate alarak cevaplamışlardır. Bulgular: Araştırmanın sonucunda, nesiller arası normatif dayanışma ile duygusal dayanışma, işlevsel dayanışma (ebeveyn/büyük ebeveyne yardımda bulunma), yapısal dayanışma (ailenin genişliği), ilişkisel dayanışma ve uzlaşımsal dayanışma ile pozitif yönde ilişki bulunmuştur. Sonuç: Araştırmada, gençlerin aileleri ile birliktelik ve bütünlüklerinin hala sürdürüldüğü, dolayısıyla dayanışma düzeylerinin orta seviyeler ve üstünde olduğu görülmüştür. Nesiller arası dayanışmanın kuvvetlendirilmesi ve sürdürülmesi doğrultusunda, bütün bu paydaşların ortak çalışmalarıyla bölgesel, toplumsal bazda programlar ve projeler geliştirilmeli ve uygulanmalıdır.

Anahtar kelimeler: Ailelerde nesiller arası dayanışma, aile desteği, bakım

Received / Geliş tarihi: 10.10.2016, Accepted / Kabul tarihi: 02.11.2016

\footnotetext{
${ }^{1}$ Hacettepe Üniversitesi İktisadi ve İdari Bilimler Fakültesi, Aile ve Tüketici Bilimleri Bölümü

*Address for Correspondence / Yazışma Adresi: Serhat Öztürk, Hacettepe Üniversitesi İktisadi ve İdari Bilimler Fakültesi 3. Kat, Aile ve Tüketici Bilimleri Bölümü 06800 Beytepe/Ankara-TÜRKIYE, E-mail: sozturk@ hacettepe.edu.tr

Öztürk S, Hazer O. Genç nesil bakışıyla ailelerde nesiller arası dayanışma. TJFMPC, 2016;10(4): 222-232. DOI: 10.21763/tjfmpc.271095
} 


\section{GíRIŞ}

Aile, bireyler arasındaki ilişkilerin gelişmesini ve sürdürülmesini sağlayan kurumlardan biridir. Aynı zamanda aile, üyeleri açısından ekonomik, sosyal ve psikolojik nitelikli bir dayanışma sistemidir. ${ }^{1}$ Günümüzde değişen aile yapısı ve hayat tarzı, nesillerin birbirleriyle ilişki, iletişim, rol ve beklentilerinde değişimlerin ortaya çıkmasına sebep olmuştur. Sanayileşme devrimleriyle birlikte, ailenin yapısında meydana gelen bu değişimler, ebeveynlerin/büyük ebeveynlerin, çocuklarından/torunlarından, ayrı yerlerde yaşamaya başlamasına ve parçalanmış ailelerin sayısında artışlar meydana gelmesine sebep olmuştur. Bunun yanı sıra, ailelerde çalışan kadınların artması ve boşanma oranlarındaki yükseliş özellikle büyük ebeveynlerin torunlarına verdikleri bakım ve maddi yardımlar gibi desteklerin, gün geçtikçe artması durumunu ortaya çıkarmıştır. 2,3

Ailelerde, nesillerin birbirinden uzaklaşmaları sonucu, yetişkinler bir taraftan iş hayatının getirdiği zorluklar, diğer taraftan anne ve babalarına yardımcı olma ve çocuklarını yetiştirme konusunda problemlerle karşılaşmışlardır. $\mathrm{Bu}$ gelişmeler, gençlerin yetişkinlerden ayrı ortamlarda daha fazla zaman geçirmesine sebep olmuştur. Bununla birlikte, nesillerin birbiriyle iletişiminin süre ve miktarında azalmalar meydana gelmiştir. ${ }^{4}$

Aile bağlarına ilişkin bu değişimlerle birlikte, son zamanlarda aile konusunda yapilan çalışmalara bakıldığında, ailelerde nesiller arası dayanışmanın önemi üzerinde durulduğu görülmektedir. $5,6,7,8,9,10,11,12$

Makro anlamda nesiller arası dayanışma; toplumlar bazında genç ve yaşlı nesiller arasında karşılıklı oluşturulabilecek dayanışma ilişkilerini ifade etmektedir. Alanyazında? ise çoğunlukla nesiller arası dayanışmanın, mikro anlamda yani aileler bağlamında incelendiği görülmektedir. ${ }^{13,14,15,16}$ Bir başka deyişle çocuklar, torunlar, ebeveynler ve büyük ebeveynler arasındaki dayanışma ve karşılıklı destek ilişkileri ifade edilmektedir ${ }^{17}$.

Yapılan bazı çalışmalarda, gencin refahı üzerinde, gencin ebeveyne/büyük ebeveyne karş1 duyduğu bağlılık, yakınlık ve olumlu tutumların önemli etkisinin olduğu belirlenirken, yine ebeveyne/büyük ebeveyne karşı duyulan yakınlık ve bağlılığın gençler ve daha yaşlı nesiller arasındaki anlaşmazlıkların azaltılmasında çok önemli bir faktör olduğu görülmektedir. ${ }^{2,18,19}$ Nitekim bu anlaşmazlıkların anlaşılması ve çözümlenmesi doğrultusunda, son zamanlarda en çok araştırılan alanlardan biri de ailelerde nesiller arası ilişkiler olmuştur. ${ }^{9}$ Özellikle yaşlı aile bireylerin bakımı konusunda ortaya çıkan endişeler, nesiller arası dayanışmanın bir boyutu olarak karşımıza çıkmaktadır. $\mathrm{Bu}$ endişelerden birisi, büyük ebeveynlerin özellikle 85 yaş üstünün, sayısı ve oranındaki artış ve bu yaşlıların sonraki yıllarda yaşlı bakımına ihtiyaç duyduklarında nasıl ve kimlerden tarafindan bakılacağ1 endişesi., ${ }^{20,21,22,23,7,24} \mathrm{Bu}$ endişe, iş gücüne katılan kadınların artması ile birlikte, büyük ebeveynlerin bakımını sağlama konusunda, üzerinde toplumdan en çok beklenti olan kadın akrabaların desteğinin azalmasıyla daha da artmaktadır. ${ }^{25,7}$

Çocuk bakımı konusunda ise, nesiller arası ilişkilerde büyük ebeveynlerin üstlendiği roller yadsınamaz. Nitekim, Türk toplumunun kültürel yapısında, torun sevgisinin ayrı bir yeri söz konusudur ve büyük/ebeveynler için torun sahibi olmak çok özel bir durumdur. Annenin de, babanın da iş hayatında yer aldığı günümüz toplumunda çocuk, okul öncesi eğitim çağına gelmemişse, anne ve babasının çalıştığı zamanlarda bir bakıcı, ya da bir aile ferdinin gözetiminde geçirmektedir. $\mathrm{Bu}$ nedenle, büyük ebeveynlerin çocuğun bakımı ve gelişiminde çok büyük katkıları olduğu görülmektedir. ${ }^{26}$

Ülkemizde, büyük şehirlerde büyük ebeveynler ile beraber yaşamak gittikçe zorlaşsa da, birçok şehirde özellikle de kırsal alanda hala büyük bir aile gibi yaşama geleneği devam etmektedir. Özellikle kadının çalışma hayatına girmesiyle, torunların büyük ebeveynlerin yanına bırakılması, ebeveynlerin çalıştığ 1 saatlerde bakım vazifesini büyük ebeveynlerin üstlenmesi farklı kuşakların bir arada yaşamasını gerektirebilmektedir. ${ }^{4}$

Diğer taraftan yaşlılık döneminde, yaşlı ebeveyn/büyük ebeveyn ile ilgilenme, ailenin sorumluluğu olarak kabul edilmektedir. Geleneksel olarak, özellikle yetişkin çocuklar bu rolü üstlenmekte ve yaşlı nesillere yaşlılıkta en önemli yardım, bakım ve sosyal iletişim kaynağ olmaktadirlar. ${ }^{27}$

Böylece yaşlı ebeveyn/büyük ebeveyn ve yetişkin çocukların karşılıklı yardım, bakım ve destek ilişkilerini paylaşılması gereken sorumluluklar olarak görmeleri, yeni rollere ilişkin davranışlar geliştirmeleri, tüm aile bireyleri arasında olumlu ilişkiler kurulmasını sağlayabilir.

Ailede, torunların dünyaya gelmesi, bir ailede üç nesil için de büyük önem taşıyan bir olaydır. Ebeveyn olan yetişkin çocuklar; pek çok konuda başvurabilecekleri, yardım alabilecekleri kendi ebeveynlerinin kıymetini daha çok anlayarak, onlara yakınlaşır ve güven duyarlar. ${ }^{28}$ Çocukların günlük hayatta ebeveynleri ile yaşadıkları sürtüşmeler, otorite-üstünlük mücadeleleri, büyük ebeveyn ile torunları arasinda daha az yaşanmaktadır. Büyük ebeveynlerin torunları ile daha iyi iletişim kurdukları, çocuklarla anne babalar arasındaki ilişkilerde görülen gerilim ve çatışmaları 
yatıştırıcı, azaltıcı, arabulucu rolü oynayabildikleri bilinmektedir. $^{29}$ Büyük ebeveynler, çoğunlukla torunlarının eğitimi ve bakımında, torunlarının yaşamlarının birçok önemli döneminde hem maddi olarak hem de emek ve zaman harcayarak önemli katkıda bulunurlar. ${ }^{30}$

Özellikle, aynı evde yaşayan nesillerin etkileşimi, bu bağlamda giderek önem kazanmaktadır. Farklı nesiller bir arada yaşadığında, karşılıklı destek ve işbirliği söz konusu olacaktır. Ebeveynler/büyük ebeveynler, çocuklarının/torunlarının ailelerine birçok yolla katkıda bulunurken (maddi, eğitim, ev işleri ve çocuk bakımı vb.) çocuklar/torunlar da bakıma ihtiyaç duyan ebeveyne/büyük ebeveyne destek vermektedirler. $^{31}$

Dünya'da ve ülkemizde görüşme türlerinde ve sıklıklarında meydana gelen değişimlere rağmen, ebeveynlerin/büyük ebeveynlerin bakıma ihtiyaç duyduklarında, sağlanması gereken uzun dönem bakımı konusunda sağlanan desteğin $\% 70$ ile $\% 80$ arasında çocuklarından geldiği görülmektedir. ${ }^{6}$ Stoller'a (1983) göre, ebeveynlere/büyük ebeveynlere verilen bu bakım ve destek; aile bağlarının gücünü, bakıma ihtiyaç duyan ebeveynlerin/büyük ebeveynlerin bakımında aile üyelerinin önemini ve bakıma ihtiyaç duyan ebeveynlerin/büyük ebeveynlerin, devlet tarafindan sağlanan bakım desteğine ilişkin tutumlarını belirlemede kilit rol oynamaktadır. $^{7}$

Ailelerde, nesiller arası dayanışmayı birçok boyutlarıyla ele alan bu konunun anlaşılmasında, önemli çalışmalar yapan Bengtson ve Roberts (1991) tarafindan geliştirilen ve altı boyutta ele alınan kuşaklararası dayanışma modelindeki boyutlar; yapısal, duygusal, ilişkisel, uzlaşımsal, işlevsel ve normatif dayanışma olarak sıralanmaktadır. ${ }^{13}$ Kuşaklararası dayanışmayı açıklamaya yönelik, en kapsamlı modellerden biri olan bu modeldeki boyutların tanımları ve ilgili dayanışmaya ilişkin örnekler şu şekilde özetlenebilir:

-Yapısal Dayanışma; aile bireylerinin sayısına, çeşitlerine ve coğrafi yakınlık derecesine göre ortaya çıkan yapısal durumlar, aile üyelerinin yerleşim yakınlı̆̆ı, aile üyelerinin sayısı, aile üyelerinin sağlı̆̆ gibi değişkenlerle ifade edilir.

-İlişkisel Dayanışma; aile bireylerinin içinde bulunduğu, her tür etkinlikteki etkileşim kalıpları ve sıklığı olarak tanımlanır. Kuşaklararası etkileşim sıklığı (yüz-yüze, telefonda, mektupla gibi), ortak aktivitelerin türleri (boş zamanlar, özel anlar gibi) gibi değişkenlerdir.

-İşlevsel Dayanışma; destek olma ve kaynak paylaşımının derecesi, karşılıklı destek olma ilişkilerinin (finansal, fiziksel, duygusal) derecesi, kuşaklararası kaynak paylaşımının karşılıklılığının derecesi gibi değişkenlerle ifade edilir.

-Duygusal Dayanışma; aile bireylerine karşı duyulan olumlu duyguların türü ve derecesi ile bu duyguların karşılıklılığı; aile üyelerine duyulan ilgi, sıcaklık, yakınlık, anlayış, güven, saygı gibi duyguların derecesi, aile üyelerine karşı duyulan olumlu duyguların karşılıklılı̆̆ına dair inancın derecesi olarak tanımlanır.

-Uzlaşımsal Dayanıșma; aile üyeleri ile değerler, tutumlar ve inançlar konusunda duyulan uzlaşının derecesi; belirli değerler, tutumlar ve inançlar konusunda ailede bireysel yönelimlerin uyumluluğu, değerler, tutumlar ve inançlar konusunda aile üyeleri ile benzer yönelimlere sahip olunduğuna duyulan inancın derecesi olarak tanımlanır.

-Normatif Dayanışma; ise aile içinde üstlenilen role bağl1lık ve yükümlülükleri yerine getirme derecesi, aileye ve kuşaklararası rollere verilen önem, evlat olarak yükümlülüklere duyulan bağlılığın derecesi olarak tanımlanmaktadır ${ }^{13}$.

Ailelerde, nesiller arası dayanışmaya ilişkin yapılan çalışmaların artması ve bu konuya olan ilginin yoğunlaşması aile yaşantısını güçlendirme, ebeveynler/büyük ebeveynler ve çocukların/torunların karşılıklı olarak birbirlerinin beklentilerini anlama ve sorunlarına çözüm yolları bulmayı kolaylaștırma açısından oldukça önemlidir. $\mathrm{Bu}$ bağlamda, ülkemizde ve dünyada nesiller arasında karşılıklı bakım gibi diğer desteklere yönelik çalışmaların artması ve politikalar oluşturulması toplumun refahı açısından çok önemlidir. $\mathrm{Bu}$ aşamada, sosyal sağlık kavramına değinmek yerinde olacaktır; Dünya Sağlık Örgütü (WHO), sosyal sağlık kavramını; kişinin bedensel ve ruhsal sağlığı üzerinde etki yapabilecek ve aynı zamanda, kendi bünye ve toplumsal çevresinden kaynaklanarak gelişen koşulların oluşturduğu, sosyal yaşantı alanındaki iyilik ve esenlik hali olarak tanımlamaktadır. ${ }^{32}$ Hem genç nesillerin, hem de yaşıı nesillerin sosyal açıdan sağlıklı bir yaşam sürdürmeleri ve yaşam kalitelerinin yükseltilmesi, dolayısıyla aile yapılarının güçlendirilmesi nesiller arasındaki dayanışmanın artırılması ve sürdürülmesi ile sağlanabilecektir. $\mathrm{Bu}$ doğrultuda bir adım atmak üzere, bu araştırma ile ailelerde nesiller arası dayanışmanın bütün boyutlarıyla incelenmesi amaçlanmıştır.

\section{YÖNTEM}

\section{Evren ve Örneklem}

Çalışmada, farklı yaş gruplarındaki (15-29 yaş) 990 gence nesiller arası dayanışmaya ilişkin sorular yöneltilmiş ve katılımcılar bu soruları annelerinden, babalarından, büyük annelerinden ya da büyük babalarından bir tanesini dikkate alarak cevaplamışlardır. ${ }^{33}$ 
Araştırmanın evrenini, Ankara'da ikamet eden ve sosyo-ekonomik düzeyleri farklılık gösteren bireyler oluşturmaktadır. $\mathrm{Bu}$ seçim aşamasında; Ankara ilinin ilçelerinin, sosyoekonomik düzeylerine göre dağılım bilgilerine ulaşmak için, Türkiye İstatistik Kurumu'ndan (TÜİK, 2016) alınan verilerden yararlanılmıştır. ${ }^{33}$ $\mathrm{Bu}$ listedeki 15-29 yaş arası birey sayısı 528.310'dur. Bütün yaş gruplarının dahil olduğu toplam nüfus ise 2.176.099'dur. Örneklem sayıs1, her bölgedeki TÜİK (2016) tarafindan belirlenen yaş gruplarının nüfusa göre dağılımı dikkate alınarak (990 genç) belirlenmiştir. Ankara ilindeki 25 ilçe, üç sosyo-ekonomik düzeye göre gruplandırılmış ve bu gruplandırma sonrasında yapılan basit rastgele örnekleme yöntemi arasından 'Çankaya' ilçesi yüksek sosyo-ekonomik düzey (YSED), 'Keçiören' ilçesi orta sosyo-ekonomik düzey (OSED) ve 'Altındağ' ilçesi düşük sosyoekonomik düzey (DSED) olarak seçilmiştir. Bu ilçelerden, araştırma kapsamına alınacak bireylerin seçilmesinde ise, her bölgedeki TÜİK (2016) tarafından belirlenen yaş gruplarının nüfusa göre dağılımı dikkate alınarak sayılar belirlenmiştir. ${ }^{33}$ Araştırmada, nüfustaki farklı bölümlerin yeterince temsil edilmesini sağlamak ${ }^{34}$ amaciyla örneklem seçiminde, tabakalı tesadüfî örnekleme yöntemlerinden ele alınan örneğin, tabakalar arasında paylaştırılmasının en basit ve sık kullanılan yolu olan "orantılı paylaştırma" (oransal tabakalı örnekleme) yöntemi kullanılmıştır. ${ }^{35}$ 15-19 yaş aralığında olanların 131'inin Keçiören, 114'ünün Çankaya ve 56'sı Altındağ'da; 20-24 yaş aralığında olanların ise 163'ünün Çankaya, 128'inin Keçiören, 55'inin Altındağ'da; son olarak da 25-29 yaş grubunda yer alanların ise 146'sının Keçiören, 141'inin Çankaya ve 56'sı Altındağ'da ikamet etmektedir. Belirlenen bu ilçelere ve yaş gruplarına göre kartopu örnekleme yöntemi ile araştırma katılımcılarına ulaşılmıştır.

\section{Veri Toplama Aracı}

Araştırmada, katılımcıların ailelerde nesiller arası dayanışma boyutlarını belirlemeye ilişkin soru ve ölçekler ile sosyo-demografik özelliklerini belirleyici bir soru formu kullanılmıştır. Çalışmada, genel sorular hariç 23 soru sorulmuştur. $\mathrm{Bu}$ soru formları ve ölçekler şu şekilde sıralanabilir:

\section{Ailelerde Nesiller Arası Yapısal Dayanıșma}

Ailelerde nesiller arası yapısal dayanışma; ailede yaşayan kişi sayısı, ebeveyn/büyük ebeveynle olan coğrafi uzaklık, ebeveynin/büyük ebeveynin genel sağlık durumu ve katılımcının genel sağlık durumu gibi sorularla ölçülmektedir. ${ }^{38,9}$ Ailede yaşayan kişi sayısı ailenin genişliğini ifade etmektedir. Coğrafi uzaklık; (0) aynı evde , (1) aynı sokakta/aynı semtte, (2) aynı semtte vasita ile ulaşılabilir, (3) aynı şehirde vasıta ile ulaşılabilir, (4) farklı şehir veya memlekette olmak üzere, 0 ile 4 aralığında kodlanmıştır. Sonrasında bu ifadeler ters kodlanarak puanlanmıştır. Katılımlardan alınan puan yükseldikçe, coğrafi uzaklık azalmaktadır. Ebeveynin/Büyük ebeveynin sağlık durumunu ve katılımcının sağlık durumunu belirlemek için; (0) kötü ile (3) mükemmel aralığında olmak üzere verilen cevaplar 0 ile 3 aralığında kodlanmıştır. Katılımcıların aldıkları puan yükseldikçe, sağlık durumu iyileşmektedir.

\section{Ailelerde Nesiller Arası İlişkisel Dayanışma}

Ailelerde, nesiller arası ilişkisel dayanışmayı belirlemek amacıyla, katılımcıların ebeveynleri/büyük ebeveynleri ile görüşme sıklıklarının ele alındığ 1 , Mangen ve Miller'ın (1988) kullandığ1 4 soru kullanılmıştır. ${ }^{39}$ Bu sorulardan ilki, 'ebeveyniniz/büyük ebeveyniniz ile telefonla ne sıklıkta görüşüyorsunuz?' sorusudur. Diğer sorular ise katılımcıların ebeveynlerini/büyük ebeveynlerini, ziyaret etme sıklıklarını, aile toplantıları, özel günler (doğum, ölüm, yaş günü, mezuniyet vb.) ya da bayramlarda yapılan görüşme sıklıklarını, katılımcı için önemli konularda yapılan görüşme sıklıklarını belirlemeye yöneliktir. $\mathrm{Bu}$ sorulara; (0) günde en az bir kere ile 6) yılda bir kere ya da daha az şeklinde verilen cevaplar, 0 ile 6 aralığında kodlanmıştır. Bu kodlamalar daha sonra ters kodlanarak, toplam puan hesaplanmıştır. Sorulan 4 sorudan, 0-24 arasında bir puan elde edilmiştir. Alınan puanlar yükseldikçe, ailelerdeki nesiller arası ilişkisel dayanışmanın da yükseldiği görülmektedir.

\section{Ailelerde Nesiller Arası İşlevsel Dayanışma}

Ailelerde, nesiller arası işlevsel dayanışmayı belirlemeye yönelik sorular Netzer'in (1994) Lee'den (1994) uyarladığı biçimiyle kullanılmıştır. ${ }^{9,40}$ Belirlenen her bir 6 faaliyet/konu ilişkin son 6 ayda katılımcının, ebeveyne/büyük ebeveyne yardım etme durumu ile katılımcının ebeveynden/büyük ebeveynden yardım alma durumu incelenmiştir. Belirlenen bu 6 faaliyetlerde/konularda; bir karar için öneri, finansal yardım (karşılıksız ya da borç olarak), para dışındaki hediyeler, ev işlerinde yardım (tamir, eşya taşıma, yemek yapma, temizlik yapma vb.), ulaşımla ilgili destek, bebek ya da çocuk bakıcılığı yardımı yardım alma ve yardım verme durumları ayrı ayrı puanlanıp, analiz edilmiştir. Katılımcıların ebeveynlerinden/büyük ebeveynlerinden yardım aldıkları her faaliyette/konuda 'evet' diyenler 1 puan, 'hayır' diyenler 0 puan almış ve bu puanlar toplanmıştır. 6 faaliyetten/konudan, 0-6 arasında bir puan elde edilmiştir. Alınan puanlar yükseldikçe, ailelerdeki nesiller arası işlevsel dayanışma da yüksek olmaktadır. Yine aynı şekilde; katılımcıların ebeveynlerinden/büyük ebeveynlerinden yardım 
verdikleri her faaliyette/konuda, 'evet' diyenler 1 puan, 'hayır' diyenler 0 puan almıştır ve bu puanlar toplanmıştır. 6 faaliyetten/konudan, 0-6 arasında bir puan elde edilmiştir. Alınan puanlar yükseldikçe, ailelerdeki nesiller arası işlevsel dayanışma da yüksek olmaktadır.

\section{Ailelerde Nesiller Arası Duygusal Dayanışma}

Ailelerde, nesiller arası duygusal dayanışmayı incelemek için Mangen, Bengtson ve Landry (1988) tarafından geliştirilen ölçek kullanılmıştır. ${ }^{41}$ Ölçekte 5 soru yer almaktadır; bu sorulardan ilki, 'hayatınızın bu aşamasında her şeyi göz önünde bulundurarak düşündüğünüzde, ebeveyniniz/büyük ebeveyniniz ile olan ilişkinizi ne kadar yakın hissediyorsunuz?' dur. Bu soruya verilen yanitlar; (1) çok yakın hissetmiyorum ve (5) çok yakın hissediyorum olmak üzere, 1 ile 5 aralığında kodlanmıştır. Diğer 4 soru ise; 'ebeveyniniz/büyük ebeveyniniz ile olan iletişiminizi nasıl tanımlarsınız?', 'ebeveyniniz/büyük ebeveyniniz ile hayatınızın bu evresindeki ilişkilerinizi nasıl tanımlarsınız?', 'ebeveyninizi/büyük ebeveyninizi ne kadar iyi anladığınızı düşünüyorsunuz?', 'ebeveyninizin/büyük ebeveyninizin sizi ne kadar iyi anladığını düşünüyorsunuz?' sorularından oluşmaktadır. Bu sorulara verilen yanıtlar ise; (1) hiç iyi değil ile (5) çok iyi, olmak üzere 1 ile 5 aralığında kodlanmıştır. Yapılan faktör analizi sonucunda, bu ölçekteki ilk ifade çıkarılmıştır. Çıkarılan ilk soru dışındaki 4 soruya ilişkin cevaplardan alınan puanlar toplanarak, 4 ile 20 arasında bir puan elde edilmiştir. Katılımcıların aldıkları puan yükseldikçe, ailelerde nesiller arası duygusal dayanışmanın da yüksek olduğu belirlenmektedir. Parrott \& Bengtson (1999) tarafindan yapılan çalışmada, 5 maddenin de faktör yükleri 0,80'in üzerinde çıkmıştır, ölçek tek boyutlu çıkmıştır ve Chronbach's alpha güvenirlik katsayısı of 0.80 bulunmuştur. ${ }^{42} 1$. madde çıkarılmadan önce 0,81 olan Chronbach's alpha güvenirlik katsayısı, 1 . madde çıkarıldıktan sonra ölçeğin Chronbach's alpha güvenirlik katsayısı 0,88 olarak bulunmuştur.

\section{Ailelerde Nesiller Arası Uzlaşımsal Dayanışma}

Ailelerde nesiller arası uzlaşımsal dayanışmaya ilişkin soru, Bengtson ve Roberts'in (1991) kullandığ1 şekliyle kullanılmıştır; eEbeveyniniz/büyük ebeveyniniz ile hayatla ilgili düşünce ve görüşleriniz genelde ne kadar benzerdir?' Bu soruyu cevaplayan katılımcilar; (1) 'tamamen farkl1' ve (6) 'tamamen benzer' ifadelerini 1 ile 6 arasında bir puanlamışlardır. ${ }^{13} \mathrm{Bu}$ soruya verilen cevaplardan, 1-6 arasında bir puan elde edilmiştir. Alınan puan yükseldikçe, ailelerin uzlaşımsal dayanışmaları da yükselmektedir.

\section{Ailelerde Nesiller Arası Normatif Dayanışma}

Ailelerde nesiller arası normatif dayanışmada, Netzer (1994) tarafindan daha önce yapılan çalışmalardan ${ }^{9,43,44,45,46}$ yola çıkılarak geliştirilen ölçek kullanılmıştır. Ölçekte 9 ifade yer almaktadır, bu ifadeler şunlardır; 'yaşlı bir kişinin karşılayamayacağı sağlık harcamasını, oğlu ya da kızı ödemek zorundadır' gibi ifadelere verilen cevaplar ise; (1) kesinlikle katıliyorum ile (4) kesinlikle katılmıyorum olmak üzere, 1 ile 4 aralığında kodlanmıştır. Katılımcılara istedikleri soruları cevaplamama özgürlüğü verilmiştir; bu nedenle, Netzer'in (1994) belirlediği puanlama sistemindeki gibi, cevaplanan soruların puanları toplanmış ve cevaplanan soru sayısına bölünmüş ve seçenek sayısı (4) ile çarpılmıştır. ${ }^{9} \mathrm{Bu} 9$ ifadeye verilen cevaplardan, 4 ile 16 arasında bir puan aralığı ortaya çıkmıştır. Katılımcıların aldıkları puanlar yükseldikçe, nesiller arası normatif dayanışma da yükselmektedir. Netzer (1994), tarafından yapılan çalışmada ise, 9 maddenin de faktör yükleri 0,48 'in üzerinde çıkmıştır, ölçek üç boyutludur ve Chronbach's alpha güvenirlik katsayıs1 of 0.68 bulunmuştur. ${ }^{9}$ Analizler sonucunda, nesiller arası duygusal dayanışma ölçeği ve normatif dayanışma ölçeğinin geçerli ve güvenilir olduğu belirlenmiştir.

\section{Sosyo Demografik Özellikler}

$\mathrm{Bu}$ formda katılımcıların cinsiyeti, katılımcının eğitim, algıladığı gelir ve medeni durumu ve aile tipine ilişkin bilgiler yer almaktadır.

\section{Verilerin Toplanması}

Araştırma soru formuna ilişkin, Hacettepe Üniversitesi Etik Kurul İzni 12 Ocak 2016 tarihinde alınmıştır. Araştırma verileri, Mayıs-Haziran 2016 tarihleri arasında Ankara ilinin Çankaya, Keçiören ve Altındağ ilçelerinde yaşayan 15-29 yaş arasındaki gönüllü katılımcılarla yüz yüze anket yöntemi kullanılarak elde edilmiştir.

\section{Verilerin Değerlendirilmesi ve Analizi}

Araştırmada, katılımcılara ve katılımcıların yapılan çalışmada hakkında cevap verdikleri ebeveyn/büyük ebeveynleri ilişkin demografik ve tanımlayıc1 bilgiler, frekans, yüzde, ortalama ve standart sapma gibi tanımlayıcı istatistiklerle ifade edilmiştir (Katılımcıların yaş gruplarına göre dağılımı, cinsiyeti, eğitim, aylık gelir durumu, çalışma, medeni durum, kardeş sayıları ve kiminle birlikte yaşadığı, katılımcılara anketin hangi ebeveyn/büyük ebeveyn hakkında yapıldığı, ebeveyn/büyük ebeveyn yaş grupları, ebeveyn/büyük ebeveyn eğitim ve çalışma durumu). Ailelerde, nesiller arası dayanışma boyutları (normatif dayanışma, yapısal dayanışma, ilişkisel dayanışma, işlevsel dayanışma, uzlaşımsal dayanışma, duygusal dayanışma) arasındaki ikili ilişkilerin yönü ve gücü ise, Çift Yönlü Pearson Korelasyon Analizi ile belirlenmiştir. 


\section{BULGULAR}

Ankara'da 15-29 yaş arası 990 genç ile yapılan bu araştırma ile, ailelerde nesiller arası dayanışma boyutlarını (normatif, duygusal, ilişkisel, işlevsel, uzlaşımsal ve yapısal dayanışma) ve bu boyutlar arasındaki ilişkinin incelenerek aile yaşantısını güçlendirme, nesiller arası beklentilerin anlaşılması ve nesiller arasındaki sorunlara çözüm yolları bulunması amaçlanmıştır.

\section{Katılımcılar İle İlgili Genel Bulgular}

Araştırma kapsamına alınan katılımcıların yaş grupları incelendiğinde, 15-19 yaş arasındakilerin $\% 30,4,20-24$ yaş arasındakilerin \%34,9, 25-29 yaş arasındakilerin ise \%34,6 oranında olduğu görülmektedir. Katılımcıların \%60,4'ü kadın, \%39,6's1 ise erkektir. Katılımcıların eğitim durumlarına bakıldığında, yarısından fazlasının $(\% 64,6)$ üniversiteye devam ettiği ya da üniversite mezunu olduğu görülmektedir. Katılımcıların algıladıkları gelir düzeyine bakıldığında, büyük çoğunluğunun algıladıkları gelir düzeyinin orta olduğu $(\% 75,1)$ saptanmıştır. Tablo 1'de görüldüğü üzere araştırmaya katılanların \%81,3'ü bekar iken, $\% 18,7$ 'si ise evlidir. Katılımc1ların aile tipi incelendiğinde ise; büyük çoğunluğunu çocuklu ailelerin (\%70) oluştururken; bunu \%11,6 ile geniş aile tipine sahip olanlar izlemektedir (Tablo 1).

Tablo 1. Katılımcllar ile ilgili genel bulgular

\begin{tabular}{|c|c|c|c|}
\hline & & Kişi Sayısı (N) & Yüzde (\%) \\
\hline \multirow[t]{3}{*}{ Katılımcı Yaş Grupları } & $15-19$ & 301 & 30,4 \\
\hline & $20-24$ & 346 & 34,9 \\
\hline & $25-29$ & 343 & 34,6 \\
\hline \multirow[t]{2}{*}{ Katılımcının Cinsiyeti } & Erkek & 392 & 39,6 \\
\hline & Kadın & 598 & 60,4 \\
\hline \multirow[t]{7}{*}{ Katılımcının Eğitim Durumu } & Ortaokul veya daha az & 7 & 0,7 \\
\hline & Lise devam ediyor & 160 & 16,2 \\
\hline & Lise & 53 & 5,4 \\
\hline & Üniversite devam ediyor & 443 & 44,7 \\
\hline & Üniversite & 197 & 19,9 \\
\hline & Lisansüstü devam ediyor & 53 & 5,4 \\
\hline & Lisansüstü & 77 & 7,8 \\
\hline \multirow[t]{3}{*}{ Katılımcının Algıladığı Gelir Durumu } & Düşük & 147 & 14,8 \\
\hline & Orta & 743 & 75,1 \\
\hline & Yüksek & 100 & 10,1 \\
\hline \multirow[t]{2}{*}{ Katılımcının Medeni Durum } & Bekar & 805 & 81,3 \\
\hline & Evli & 185 & 18,7 \\
\hline \multirow[t]{5}{*}{ Katılımcının Aile tipi } & Tek kişilik aile & 37 & 3,7 \\
\hline & Çocuksuz aile & 73 & 7,4 \\
\hline & Çocuklu aile & 693 & 70,0 \\
\hline & Geniş Aile (3 kuşak) & 115 & 11,6 \\
\hline & Tek ebeveynli çocuklu aile & 72 & 7,3 \\
\hline Toplam & & 990 & 100 \\
\hline
\end{tabular}

\section{Ailelerde Nesiller Arası Dayanışma}

$\mathrm{Bu}$ araştırmada, ailelerde nesiller arası normatif, duygusal, işlevsel, yapısal, ilişkisel ve uzlaşımsal puan ortalamaları hesaplanarak dayanışma düzeyleri belirlenmiş ve dayanışma boyutları arasındaki ilişkiler korelasyon katsayıları ile incelenmiştir.

Katılımciların duygusal $(15,57 \pm 3,35)$ ve normatif dayanışma $(11,94 \pm 1,91)$ puan ortalaması yüksek düzeylere yakındır. Araştırmaya katılanların uzlaşımsal $(3,66 \pm 1,25)$, ilişkisel $(14,40 \pm 5,29)$ ve işlevsel dayanışma [ebeveyn/büyük ebeveynden yardım alma $(3,42 \pm 1,66)$ ve ebeveyn/büyük ebeveyne yardım verme $(3,37 \pm 1,58)]$ puan ortalamalarının ise orta düzeyin biraz üstünde olduğu belirlenmiştir. Ailelerde nesiller aras1 yapısal dayanışmaya bakıldığında ise; ailede yaşayan kişi sayısının ortalaması $3,21( \pm 1,68)$ iken; ebeveyn/büyük ebeveynle olan coğrafi uzaklık ortalaması $3,12 \quad( \pm 1,81) \quad$ dir. Ebeveynin/büyük ebeveynin genel sağl1k durumu ortalaması ise $2,65( \pm 0,65)$ ve katılımcının genel sağlık durumu ortalamas 12,99( $\pm 0,59)$ dur (Tablo 2).

Dayanışma boyutları arasındaki ilişkiler incelendiğinde ise; nesiller arası normatif dayanışmanın, duygusal $(\mathrm{r}=0,129)$, işlevsel (ebeveyn/büyük ebeveyne yardım verme) $(\mathrm{r}=0,125)$, yapısal (ailenin genişliği) $(\mathrm{r}=0,151)$, ilişkisel $(\mathrm{r}=0,090)$ ve uzlaşımsal dayanışma $(\mathrm{r}=0,222)$ ile pozitif yönde ilişkili olduğu bulunmuştur.

Araştırmada alanyazına da uygun bir biçimde ilişkiler ve yön bakımından beklenen sonuçlar bulunmuştur (Tablo 3). ${ }^{13,40,9,47,48}$

Nesiller arası normatif dayanışma ile yapısal dayanışma (ebeveyn/büyük ebeveyn ile olan coğrafi uzaklıkla) (r=-0,087) ise negatif yönde ilişkili bulunmuştur (Tablo 3 ). 
Tablo 2. Katılımcıların ailelerde nesiller arası dayanışma boyutlarına iliş̧kin ortalama ve standart sapma değerleri

\begin{tabular}{|c|c|c|c|}
\hline \multicolumn{2}{|c|}{ Ailelerde Nesiller Arası Dayanışma Boyutları } & \multirow{2}{*}{$\begin{array}{c}\text { Ortalama } \\
11,94 \\
\end{array}$} & \multirow{2}{*}{$\begin{array}{c}\begin{array}{c}\text { Standart } \\
\text { Sapma }\end{array} \\
1,91 \\
\end{array}$} \\
\hline Normatif Dayanışma & Aralık: (4-16) & & \\
\hline Duygusal Dayanışma & Aralık: (4-20) & 15,57 & 3,35 \\
\hline $\begin{array}{l}\text { İşlevsel Dayanışma } \\
\text { Ebeveyne/ Büyük Ebeveyne Verilen Yardım }\end{array}$ & Aralik: $(0-6)$ & 3,37 & 1,58 \\
\hline Ebeveynden/ Büyük Ebeveynden Alınan Yardım & Aralık: $(0-6)$ & 3,42 & 1,66 \\
\hline $\begin{array}{l}\text { Yapısal Dayanışma } \\
\text { Aile Genişliği }\end{array}$ & Aralık: $(1-13)$ & 3,21 & 1,68 \\
\hline Cografi Uzaklik & Aralık: $(0-4)$ & 3,12 & 1,81 \\
\hline Ebeveyn Sağlık Durumu & Aralık: $(0-3)$ & 2,65 & 0,65 \\
\hline Katılımcının Genel Sağlık Durumu & Aralık: $(0-3)$ & 2,99 & 0,59 \\
\hline İlişkisel Dayanışma & Aralık: $(0-24)$ & 14,40 & 5,29 \\
\hline Uzlaşımsal Dayanışma & Aralık: (1-6) & 3,66 & 1,25 \\
\hline
\end{tabular}

Tablo 3. Ailelerde nesiller arası dayanışma boyutları arasındaki korelasyona ilişkin bulgular

\begin{tabular}{|c|c|c|c|c|c|c|c|c|c|c|}
\hline & \multirow{3}{*}{$\begin{array}{c}\text { Normatif } \\
\text { Dayanıșma }\end{array}$} & \multirow{3}{*}{$\begin{array}{c}\text { Duygusal } \\
\text { Dayanıșma }\end{array}$} & \multicolumn{2}{|c|}{ Ișlevsel Dayanıșma } & \multicolumn{4}{|c|}{ Yapısal Dayanıșma } & \multirow{3}{*}{$\begin{array}{c}\text { İlișkisel } \\
\text { Dayanıșma }\end{array}$} & \multirow{3}{*}{$\begin{array}{l}\text { Uzlasumsal } \\
\text { Dayanıșma }\end{array}$} \\
\hline & & & & & \multirow[b]{2}{*}{$\begin{array}{c}\text { Aile } \\
\text { Genişliği }\end{array}$} & \multirow[b]{2}{*}{$\begin{array}{l}\text { Coğrafi } \\
\text { Uzakllk }\end{array}$} & \multirow{2}{*}{$\begin{array}{l}\text { Ebeveyn/Büyük } \\
\text { Ebeveyn } \\
\text { Sağllk Durumu }\end{array}$} & \multirow{2}{*}{$\begin{array}{c}\text { Katılımc1 } \\
\text { Sağlık } \\
\text { Durumu }\end{array}$} & & \\
\hline & & & $\begin{array}{l}\text { Yardim } \\
\text { Verme }\end{array}$ & $\begin{array}{l}\text { Yardim } \\
\text { Alma }\end{array}$ & & & & & & \\
\hline Normatif Dayanıșma & 1 & & & & & & & & & \\
\hline Duygusal Dayanışma &, $129^{* *}$ & 1 & & & & & & & & \\
\hline $\begin{array}{l}\text { İșlevsel Dayanıșma } \\
\text { Yardım Verme }\end{array}$ &, $125^{* *}$ &, $130^{* *}$ & 1 & & & & & & & \\
\hline Yardım Alma & 054 &, $125^{* *}$ &, $612^{* *}$ & 1 & & & & & & \\
\hline $\begin{array}{r}\text { Yapısal Dayanıșma } \\
\text { Aile Genişliği }\end{array}$ &, $151^{* *}$ &,- 051 &,- 046 &,$- 076^{*}$ & 1 & & & & & \\
\hline Coğrafi Uzakllk & $-087^{* *}$ & .050 & -.024 & -.022 & $-248^{* *}$ & 1 & & & & \\
\hline $\begin{array}{c}\text { Ebeveyn/Büyük Ebeveyn } \\
\text { Sağllk Durumu }\end{array}$ &,- 036 &, $149^{* *}$ &,- 011 &, 038 &,$- 079^{*}$ &,- 036 & 1 & & & \\
\hline Katulımc1 Sağlık Durumu &, 037 &, $117^{* *}$ &,- 016 &,- 038 &,- 043 &,- 028 & $360^{\circ *}$ & 1 & & \\
\hline İlişkisel Dayanıșma &, $090^{* *}$ &, $114^{* *}$ &, $226^{* *}$ &, $236^{* *}$ &, 010 &,$- 366^{* *}$ &, 015 &, 005 & 1 & \\
\hline Uzlassımsal Dayanışma &, $222^{* *}$ &, $505^{* *}$ &, $077^{*}$ &, $142^{* *}$ &,- 033 &,- 001 &, $138^{* *}$ &, $093^{* *}$ &, $130^{4 *}$ & 1 \\
\hline
\end{tabular}

** Korelasyon 0.01 anlamlılık düzeyinden anlamlı. * Korelasyon 0.05 anlamlılık düzeyinde anlamlı.

Duygusal dayanışma ile işlevsel [ebeveyn/büyük ebeveyne yardım verme, $(\mathrm{r}=0,130)$ ve ebeveyn/büyük ebeveynden yardım alma, $(\mathrm{r}=0,125)]$ yapısal [(ebeveyn/büyük ebeveyn sağlık durumu $(\mathrm{r}=0,149)$ ve katılımcının sağlık durumu $(\mathrm{r}=0,117)]$, ilişkisel $(\mathrm{r}=0,114)$ ve uzlaşımsal dayanışma $(r=0,505)$ ile pozitif yönde ilişkili bulunmuştur $(\mathrm{p}<0.01)$ (Tablo 3$)$.

Nesiller arası işlevsel dayanışmanın ebeveyn/büyük ebeveyne yardım verme boyutu ile, ebeveyn/büyük ebeveynden yardım alma boyutu $(\mathrm{r}=0,612)$, ilişkisel $(\mathrm{r}=0,226)$ ve uzlaşımsal dayanışma $(\mathrm{r}=0,077)$ ile pozitif yönde ilişkili bulunmuştur. Nesiller arası işlevsel (ebeveyn/büyük ebeveyne yardım alma) ile yapısal dayanışma (katılımcının aile genişliği) $(r=-0,76)$ arasında negatif yönlü bir ilişki varken; ilişkisel $(r=0,236$, $\mathrm{p}<0.01)$ ve uzlaşımsal dayanışma $(\mathrm{r}=0,142)$ arasında pozitif yönde bir ilişki mevcuttur (Tablo 3).

Nesiller arası yapısal dayanışmada katılımcının aile genişliği ile yapısal dayanışmada ebeveyn/büyük ebeveyn ile olan coğrafi uzaklık $(\mathrm{r}=-0,248, \quad \mathrm{p}<0.01)$ ve yapısal dayanışmada ebeveyn/büyük ebeveyn sağlik durumu arasında negatif yönlü bir ilişki vardır $(r=-0,079, p<0.05)$. Nesiller arası yapısal dayanışmada, coğrafi uzaklık ilişkisel dayanışma $(\mathrm{r}=-0,366)$ ile negatif yönde ilişkilidir. Yapısal dayanışmada, ebeveyn/büyük ebeveyn sağlık durumu ile katılımcının sağlık 
durumu $(\mathrm{r}=0,360)$ ve uzlaşımsal dayanışma $(\mathrm{r}=0,138)$ arasında pozitif yönlü bir ilişki bulunmuştur $\quad(p<0.01)$. Yapısal dayanışma (katılımcı sağlık durumu) ile uzlaşımsal dayanışma $(\mathrm{r}=0,093)$ ve nesiller arası ilişkisel dayanışma ile uzlaşımsal dayanışma $(\mathrm{r}=0,130)$ arasında pozitif yönlü bir ilişki vardır $(\mathrm{p}<0.01)$ (Tablo 3$)$.

\section{TARTIŞMA}

$\mathrm{Bu}$ araştırmada, ailelerde nesiller arası normatif, duygusal, işlevsel, yapısal, ilişkisel ve uzlaşımsal puan ortalamaları hesaplanarak dayanışma düzeyleri belirlenmiş ve dayanışma boyutları arasındaki ilişkiler incelenmiştir.

$\mathrm{Bu}$ çalışmada, ailelerde nesiller arası dayanışma boyutları arasında en yüksek dayanışma puan ortalamalarına sahip boyut duygusal ve normatif dayanışma olmuştur. Duygusal dayanışmanın yüksek olması, aile üyelerine olan bağlılık, yakınlık, güven ve saygının halen güçlü bir şekilde sürdürüldüğü sonucu çıkarılabilir. Netzer (1994) tarafından ABD'de yapılan çalışmada da duygusal dayanışma yükssek düzeylerde bulunmuştur. ${ }^{9}$

Çalışmamızda, katılımcıların yüksek dayanışma puanlarına sahip olduğu bir diğer dayanışma boyutu ise normatif dayanışmadır. Normatif dayanışmanın yüksek düzeylerde olması, katılımcıların aile içinde üstlenilen role bağlılık, yükümlülüklerini yerine getirme ve nesiller arası rollere evlat olarak verilen önemi göstermektedir. ABD'de yapılan bazı çalışmalarda $^{9,42}$ ise normatif dayanışmanın orta düzeylerde olduğu görülmüştür. Aile bireylerinin etkileşim sıklığı ve ortak aktivitelerinin incelendiği ilişskisel dayanışma, orta düzeyin biraz üstünde bulunmuştur. Kadının iş hayatına katılması, iş hayatının getirdiği zorluklar, iletişim sıklıkları ve türlerindeki değişimler gençlerin yetişkinlerden ayrı ortamlarda daha fazla zaman geçirmesine sebep olmuş ve bununla birlikte de nesillerin birbiriyle iletişiminin süre ve miktarında azalmalar meydana gelmiştir. Nitekim bu çalışmaya benzer şekilde Netzer (1994), Bengtson (1991), Lee (1994) tarafından ABD'de yapılan çalışmalarda da ilişkisel dayanışmanın orta düzeylerde olduğu belirlenmiştir. ${ }^{9,13,40}$

Araştırmada, bir başka nesiller arası dayanışma boyutu olan uzlaşımsal dayanışma da, orta düzeylerin biraz üstünde olup, bu durum aile üyelerinin değerler, tutumlar ve inançlar konusunda orta derecede benzer yönelimlere sahip olduğunu göstermektedir.

Finansal, fiziksel ve duygusal olarak, nesillerin karşılıklı destek olmasını ve kaynaklarının paylaşımlarının incelendiği işlevsel dayanışma, gençlerin hem ebeveyne/büyük ebeveyne yardım verme hem de ebeveynden/büyük ebeveynden yardım alma açısından orta düzeylerin biraz üstündedir. Ülkemizde, Kalaycığlu (2012) ve Baran ve ark. (2012) yapılan diğer çalışmalarda da benzer şekilde nesiller arasında kaynak paylaşımı orta düzeylerde bulunurken, Netzer (1994) tarafından ABD'de yapılan çalışmada ise, işlevsel dayanışma hem yardım verme hem yardım alma açısından çok düşük oranlardadır. ${ }^{9,11,12} \mathrm{Bu}$ durum, ülkemizde nesiller arasındaki dayanışmanın değişen hayat şartlarına rağmen halen devam ettiğini göstermektedir.

Dayanışma boyutları arasındaki ilişkiler incelendiğinde ise, nesiller arası normatif dayanışmanın, duygusal, işlevsel (ebeveyn/büyük ebeveyne yardım verme), yapısal (ailenin genişliği), ilişkisel ve uzlaşımsal dayanışma ile pozitif yönde ilişkili olduğu bulunmuştur. Araştırmada, alanyazına da uygun bir biçimde ilişkiler ve yön bakımından beklenen sonuçlar bulunmuştur. $13,40,9,47,48$

Nesiller arası normatif dayanışma ile yapısal dayanışma (ebeveyn/büyük ebeveyn ile olan coğrafi uzaklıkla) ise negatif yönde ilişkili bulunmuştur. Dolayısıyla ailelerin yaşadıkları yerlerin arasındaki mesafeler arttıkça, normatif dayanışmanın da azalacağı söylenebilir. Nitekim Netzer (1994) çalışmasında coğrafi uzaklığın artmasıyla ebeveynler/büyük ebeveynler arasında iletişimin ve yakınlığın da azaldığı, birbirlerinin hayatlarında daha az söz sahibi olmaya başladıklarını ve bu nedenle toplumsal normlar üzerine tutum ve davranışlarının farklılaştığını ifade etmiştir. ${ }^{9}$

Duygusal dayanışma ile işlevsel [ebeveyn/büyük ebeveyne yardım verme ve ebeveyn/büyük ebeveynden yardım alma] yapısal [(ebeveyn/büyük ebeveyn sağlık durumu ve katılımcının sağlık durumu], ilişkisel ve uzlaşımsal dayanışma ile pozitif yönde ilişkili bulunmuştur. Rossi ve Rossi (1990) ve Bengtson ve Roberts (1991) tarafından yapılan çalışmalarda da, duygusal dayanışmanın ilişkisel ve işlevsel dayanışma ile pozitif ilişkili olduğu görülmektedir. ${ }^{49,13}$ Nitekim aile bireylerine duyulan sevgi, sayg1 gibi olumlu duyguları ifade eden duygusal dayanışma ile karşılıklı yardımda bulunmayı ifade eden işlevsel ve değer birliğini ifade eden uzlaşımsal dayanışmanın pozitif bir ilişki içinde olması beklenen bir sonuçtur.

Nesiller arası işlevsel dayanışmanın, ebeveyn/büyük ebeveyne yardım verme boyutu ile ebeveyn/büyük ebeveynden yardım alma boyutu, iliş̧kisel ve uzlaşımsal dayanışma ile pozitif yönde ilişkili bulunmuştur. Nesiller arası işlevsel (ebeveyn/büyük ebeveyne yardım alma) ile yapısal dayanışma (katılımcının aile genişliği) arasında negatif yönlü bir ilişsi varken, ilişkisel ve uzlaşımsal dayanışma arasında pozitif yönde bir ilişki mevcuttur. Ailelerde, nesiller arası dayanışmanın en kilit unsurlarından birisi işlevsel dayanışmadır yani aile içindeki farklı nesillerin 
birbirleri arasındaki maddi ve manevi destek alışverişidir $^{13}$. Aile üyeleri arasında dayanışma, iletişim, duygusal destek ve arkadaşça ilişkilerin yanı sıra, para, eşya ve hizmet gibi destekleri de kapsamaktadır. ${ }^{9,15,41} \mathrm{Bu}$ doğrultuda aile üyelerinin ihtiyaç ve sıkıntı zamanlarında ilk başvurulacak kişilere dönüşmesi şeklinde genel bir tercih ve eğilim de vardır. ${ }^{50}$ Nitekim çalışmada görülmektedir ki, işlevsel dayanışma ebeveyne/büyük ebeveyne yardım verme ile ebeveynden/büyük ebeveynden yardım alma pozitif bir ilişki içindedir. Benzer şekilde işlevsel dayanışmanın yardım verme boyutu ile görüşme sıklıkları ve görüşme biçimlerini ifade eden ilişkisel ve değerler, tutumlar, inançlar konusunda duyulan uzlaşıyı belirleyen uzlaşımsal dayanışma arasında pozitif yönlü bir ilişki mevcuttur. Yapısal dayanışmanın aile genişliği boyutuyla ise işlevsel dayanışmanın yardım verme boyutu arasında negatif yönlü bir ilişki olması kaynakların paylaşılacağı kişi sayısının artmasıyla birlikte kaynak paylaşımlarının doğal olarak azaldığı görüşüyle açıklanabilir.

Nesiller arası yapısal dayanışmada, katılımcının aile genişliği ile yapısal dayanışmada ebeveyn/büyük ebeveyn ile olan coğrafi uzaklık ve yapısal dayanışmada ebeveyn/büyük ebeveyn sağlık durumu arasında negatif yönlü bir ilişki vardır. Nesiller arası yapısal dayanışmada, coğrafi uzaklık ilişkisel dayanışma ile negatif yönde ilişkilidir. Yapısal dayanışmada ebeveyn/büyük ebeveyn sağlık durumu ile katılımcının sağlık durumu ve uzlaşımsal dayanışma arasında pozitif yönlü bir ilişki bulunmuştur. Yapısal dayanışma (katılımcı sağlık durumu) ile uzlaşımsal dayanışma ve nesiller arası ilişkisel dayanışma ile uzlaşımsal dayanışma arasında pozitif yönlü bir ilişki vardır. Nitekim birçok çalışmada, yapısal dayanışmanın ailelerde nesiller arası dayanışmada en önemli öncül etken olduğunu belirtmişlerdir ve yapısal dayanışma ile ilişkisel dayanışma, duygusal dayanışma ve işlevsel dayanışmanın yakın bir etkileșim içinde olduğunu belirtmişlerdir (Tablo 2). 40,13,9,41 Yapısal dayanışmada coğrafi uzaklık boyutu ile iletişim sıklığı ve türlerini inceleyen ilişkisel dayanışma arasında negatif yönlü bir ilişski olması beklenir bir durum olarak karşımıza çıkmaktadır. Nitekim nesiller arasında coğrafi uzaklık arttıkça ilişkisel dayanışmada azalacaktır.

\section{SONUÇ VE ÖNERÍLER}

Araştırma sonucunda, ailelerde duygusal ve normatif dayanışmanın yüksek düzeylerde, uzlaşımsal, ilişkisel, işlevsel dayanışmanın ise (yardım alma ve yardım verme) orta düzeylerde olduğu bulunmuştur. Nesiller arası dayanışmanın birçok boyutu arasında ise, pozitif yönlü ve anlamlı bir ilişki mevcuttur. Araştırmada, gençlerin aileleri ile birliktelik ve bütünlüklerinin hala sürdürüldüğü, dolayısıyla dayanışma düzeylerinin orta seviyeler ve üstünde olduğu görülmüştür. Aile bireylerine duyulan sevgi, saygı gibi olumlu duyguları ifade eden duygusal dayanışma ile karşılıklı yardımda bulunmayı ifade eden işlevsel dayanışma ve değer birliğini ifade eden uzlaşımsal dayanışma pozitif bir ilişki içinde bulunmuştur.

Araştırmadan elde edilen bu sonuçlar doğrultusunda, ailelerde nesiller arası dayanışmanın artırılması yönünde politika oluşturanlara, eğitimcilere, araştırmacılara, belediyelere ve sivil toplum kuruluşlarına önemli görevler düşmektedir. Nesiller arası dayanışmanın kuvvetlendirilmesi ve sürdürülmesi doğrultusunda bütün bu paydaşların ortak çalışmalarıyla bölgesel ve toplumsal bazda programlar ve projeler geliştirilmeli ve uygulanmalıdır. Nesilleri bir araya getirecek, nesiller arasındaki paylaşımları artıracak ve nesiller arasında yaşanan ve yaşanabilecek sorun ve çatışmaların çözümüne ilişkin gerçekleştirilebilecek proje ve çalışmalar, çeşitli sivil ve devlet kurumları tarafından süreğen bir biçimde desteklenmelidir. Böylelikle, bireylere nesiller arası dayanışma konusunda farkındalık sağlanacak, nesiller arası dayanışma bütün boyutları ile geliştirilebilecektir. Nesiller arası dayanışmanın geliştirilmesi, bütün nesillerin dolayısıyla da ailelerin yaşam kalitelerinin yükseltilmesini ve aile birliğinin kuvvetlendirilmesini sağlayacaktır, bu yaklaşım ve politikalar toplumun refahına katkı sağlanması yönünde çok büyük önem arz etmektedir. Çalışma, Ankara'da yaşayan gençlerle sınırlı kaldığından, ailelerdeki bütün nesiller üzerinde ve farklı bölgelerde tekrarlanmalıdır.

\section{KAYNAKLAR}

1. Hanson, SL, Saur WJ, Seelbach WC. Racial and cohort variations in filial responsibility norms. The Gerontologist 1983;23 (6): 626-31.

2. Attar-Schwartz, S, Tan JP, Buchanan A. Adolescents'perspectives on relationships with grandparents: The contribution of adolescent, grandparent, and parent-grandparent relationship variables. Children and Youth Services Review 2009; 31: 1057-1066.

3. Franklin DL. Ensuring inequality: The structural transformation of the African American family. New York: Oxford University Press, 1997. p. 134.

4. Hazer O. Ergenlerin büyük ebeveynlerinden beklentilerini etkileyen faktörlerin incelenmesi. Hacettepe Üniversitesi Sosyolojik Araştırmalar Edergisi, http://www.sdergi.hacettepe.edu.tr/oyahazer2m akale.pdf , 5 Nisan 2011. 1-22.

5. Glazer NY. The home as workshop: Women as amateur nurses and medical care providers. Gender and Society 1990; 4 (4): 479-499. 
6. Abel EK. Who Cares for the Elderly: Public Policy and the Experiences of Adult Daughters. Philadelphia: Temple University Press. 1991. p.142.

7. Stoller EP. Parental caregiving by adult children. Journal of Marriage and the Family 1983; 45: 851-858.

8. Sussman MB. Reflections on intergenerational and kin connections. Marriage and Family Review 1991; 16: 3-9.

9. Netzer JK. Intergenerational solidarity and plans for care in later life families. Yayınlanmamış Doktora tezi, University of Florida, Amerika Birleşik Devletleri, 1994, p. 67-90.

10. Bengtson V. Beyond the nuclear family: the increasing importance of multigenerational bonds. Journal of Marriage and Family 2001; 63(1):1-17.

11. Baran AG., Çoban S. Kuramsal Açıdan Kuşaklararası Dayanışma: Yaşl1-Genç İlişkileri, Kuşaklararası Dayanışma ve Aktif Yaşlanma Sempozyum Bildirileri, Grafer Tasarım Bask1 Ambalaj, Ankara. 2012. p. 189.

12. Kalaycıoğlu S. Kuşaklararası Dayanışma ve Aktif Yaşlanma, Kuşaklararası Dayanışma ve Aktif Yaşlanma Sempozyum Bildirileri, Grafer Tasarım Baskı Ambalaj, Ankara. 2012. p. 51.

13. Bengtson VL, Roberts REL. Intergenerational solidarity in aging families: An example of formal theory construction. Journal of Marriage and the Family 1991; 53:856-870.

14. Silverstein M, VL. Bengtson. Intergenerational solidarity and the structure of adult childparent relationship in american families. The American Journal of Sociology 1997; 103(2): 429-460.

15. Bengston V, Giarrusso R, Mabry JB, Silverstein M. Solidarity, conflict, and ambivalence: complementary or competing perspectives on intergenerational relationships? Journal of Marriage and the Family 2002; 64: 568-576.

16. Lowenstein A, Katz R. Living arrangements, family solidarity, and life satisfaction of two generations of immigrants in Israel. Ageing and Society 2005; 25: 749- 767.

17. Kalmijn, M. Gender differences in the effects of divorce, widowhood and remarriage on intergenerational support: Does marriage protect fathers? Social Forces 2007; 85: 10791104.

18. Ruiz S, Silverstein M. Relationships with grandparents and the emotional well-being of late adolescent and young adult grandchildren. Journal of Social Issues 2007; 63 (4): 793-808.

19. Werner EE, Smith RS. Vulnerable but invincible: A study of resilient children. New York: McGraw-Hill, 1982. p. 455.
20. Lee GR. Aging and intergenerational relations. Journal of Family Issues 1987; 8 (4): 448-450.

21. Mancini JA, Blieszner R. Aging parents and adult children: Research themes in intergenerational relations. Journal of Marriage and the Family 1989; 51: 275-290.

22. McChesney KY, Mangen DJ. Measuring family structure. In D.J. Mangen, V.L. Bengtson, \& P.H. Landry, Jr. (Eds.), Measurement of Intergenerational Relations, Newbury Park, CA: Sage Publications. 1988. pp. 56-73.

23. Shanas E. The family as a social support system in old age. The Gerontoloqist 1979; 19 (2): 169-174.

24. Soldo BJ, Agree EM. America's elderly. Population Bulletin. 1988; 41(3): 5-51.

25. Lang AM, Brody EM. Characteristics of middle-aged daughters and help to their elderly mothers. Journal of Marriage and the Family 1983; 45: 193-202.

26. Hazer O. Büyük ebeveynlerinin ergenler tarafindan algılanan özelliklerini etkileyen faktörlerin incelenmesi. Hacettepe Üniversitesi Edebiyat Fakültesi Dergisi 2012; 29: 1-19.

27. Chappell NL, living arrangements and sources of caregiving. Journal of Gerontology 1991; 46:1-8.

28. Smith PK. The psychology of grandparenthood: An international perspective London: Routledge,1991. p 233.

29. V. Aile Şurası 'Aile Destek Hizmetleri' Bildirileri, 5 - 7 Kasım 2008 / A. Çiftçi, Ankara: Aile ve Sosyal Araştırmalar Genel Müdürlüğü, 2008, 226-227.

30. Harper S, Levin S. Family care, independent living and ethnicity. Social Policy and Society 2005; 4:157-169.

31. Postigo JML, Honrubia RL. The co-residence of elderly people with their children and grandchildren. Educational Gerontology 2010; 36: 330-349.

32. Dünya Sağlık Örgütü (WHO). Turkey: Health Profile. >http://www.who.int/gho/ countries/tur.pdf $>$. Erişim tarihi: 15 Kasım 2015.

33. Türkiye İstatistik Kurumu (TÜİK), İstatistiklerle Yaşlılık. <www.tuik.gov.tr>. Erişim tarihi: 15 Kasım 2015.

34. Güneş T, Arıkan R. Tarım Ekonomisi İstatistiği. Ankara Üniversitesi Ziraat Fakültesi Yayınlar1: 1988: p. 303-306.

35. Yamane T, Alptekin E, Apaydın C, Bakır MA, Gürbüzsel E. Temel Örnekleme Yöntemleri. Literatür Yay. İstanbul. 2001. P. 323.

36. Gauvreau PM. Sampling Theory. Duxbury Press, 1993. p. 469-72.

37. Kıral G, Billor N. Bacon Temel Bileşenler Analizi ile Sapan Değerlerin Belirlenmesi. 5. 
Ulusal Ekonometri ve İstatistik Sempozyumu, Adana. 2001. p. 2060-2061.

38. Bengtson VL, Mangen DJ. Family intergenerational solidarity revisited: Suggestions for future management. In D.J. Mangen, V.L. Bengtson, \& P.H. Landry, Jr. (Eds.), Measurement of Intergenerational Relations, Newbury Park, CA: Sage Publications. 1988. p. 222-238.

39. Mangen DJ, Miller RB. Measuring intergenerational contact in the family. In D.J. Mangen, V.L. Bengtson, \& P.H. Landry, Jr. (Eds.), Measurement of Intergenerational Relations, Newbury Park, CA: Sage Publications. 1988. p. 98-125.

40. Lee GR, Coward RT, Netzer JK. Residential differences in filial responsibility expectations among older persons. Rural Sociology 1994; 59: 100-109.

41. Mangen DJ, Bengtson VL, Landry PH. Measurement of Intergenerational Relations. Newbury Park, CA: Sage Publications. 1988. p. 234

42. Parrott TM, Bengtson VL. The effects of earlier intergenerational affection, normative expectations, and family conflict on contemporary exchanges of help and support. Research On Aging 1999; 21:73-105.

43. Brody EM, Johnsen PT. Fulcomer MC. What should adult children do for elderly parents? Opinions and preferences of three generations of women. Journal of Gerontology 1984; 39: 736-746.

44. Heller PL. Familism scale: Revalidation and revision. Journal of Marriage and the Family 1976; 38: 423-429.

45. Seelbach WC, Sauer WJ. Filial responsibility expectations and morale among aged parents. The Gerontoloqist 1977; 17: 492-499.

46. Brackbill Y, Kitch D. Intergenerational relationships: A social exchange perspective on joint living arrangements among the elderly and their relatives. Journal of Aging Studies 1991; 5 (1): 77-97.

47. Lillard LA, Willis R. Motives for intergenerational transfers: evidence from Malaysia. Demography 1997; 34(1): 113-134.

48. Ross N., Hill M, Sweeting H, CunninghamBurley. Grandparents and teen grandchildren: exploring intergenerational relationships. Edinburgh: ESRC, Centre for Research on Families and Relationships, 2005. p. 324-233

49. Rossi, AS, Rossi PH. Of human bonding: Parent-child relations across the life course. New York: Aldine. 1990. p. 32

50. Treas J, Bengtson VL. The family in later years. In M.B. Sussman \& S.K. Steinmetz (Eds.), Handbook of Marriage and the Family, New York: Plenum Press. 1987. p. 625-648. 